\section{Is the management of obesity in primary health care appropriate in Brazil?}

\section{O manejo da obesidade na atenção primária à saúde no Brasil é adequado?}

\section{¿Es adecuada la gestión de la obesidad en la atención primaria en Brasil?}

\author{
Mariana Souza Lopes 1 \\ Patrícia Pinheiro de Freitas 1 \\ Maria Cecilia Ramos de Carvalho 1 \\ Nathália Luiza Ferreira 2 \\ Mariana Carvalho de Menezes 3 \\ Aline Cristine Souza Lopes 1
}

doi: 10.1590/0102-311X00051620

\begin{abstract}
This study aims to describe the adequacy of basic health units (UBS) in Brazil regarding structure and work process for obesity management and to evaluate user satisfaction with primary health care services. This cross-sectional study was conducted with data from the 2013-2014 National Program for Improving Primary Care Access and Quality (PMAQ) - an initiative to assess primary health care teams' performance. Data were collected between 2013 and 2014 through interviews with primary health care teams and users. All indicators of adequate care for obesity were defined within the article scope, based on data from the PMAQ. Of the 24,055 UBS analyzed, located in 4,845 different cities, only $7.6 \%$ had adequate structure for obesity management. Likewise, only $26.6 \%$ of the 114,615 users interviewed reported adequate access, and $27.8 \%$ of the UBS showed adequate service organization. Healthcare was considered as "good" or "very good" by $82.4 \%$ of users. These indicators varied according to geographic region, showing better results for the South and Southeast. Our results suggest that the country may still be at the initial stage of systematizing care with obesity, presenting significant disparities among regions.
\end{abstract}

Obesity; Primary Health Care; Quality of Health Care

\author{
Correspondence \\ A. C. S. Lopes \\ Universidade Federal de Minas Gerais. \\ Av. Alfredo Balena 190, Belo Horizonte, MG 30130-100, Brasil. \\ alinelopesenf@gmail.com \\ 1 Universidade Federal de Minas Gerais, Belo Horizonte, Brasil. \\ 2 Universidade Federal de Lavras, Lavras, Brasil. \\ 3 Universidade Federal de Ouro Preto, Ouro Preto, Brasil.
}




\section{Introduction}

Obesity is a global issue, with an estimate of more than six hundred million adults witth obesity worldwide 1. In Brazil, the obesity rate increased by over 60\% between 2006 and 2018, going from $11.8 \%$ to $19.8 \% 2$. Besides its health consequences, obesity imposes an economic burden on individuals, families, countries, and healthcare systems 1,3 .

Several countries around the globe have presented recommendations with a high level of evidence regarding the therapeutic assistance of overweight and individuals with obesity. A study aimed to evaluate and describe the quality of clinical guidelines for the treatment of obesity in adults from different countries identified 20 guidelines: nine from Europe, six from North America, three from Latin America, one from Asia, and one from Oceania 4 . However, the practice of adequate nutrition therapies in primary and secondary healthcare leading to satisfactory outcomes remains rare in different countries and contexts 5 .

Considering the healthcare system and its guidelines, primary health care (PHC) units are key to addressing the challenges of obesity management in Brazil. PHC approach to obesity should include (but not be limited to) health promotion, food and nutrition surveillance, health education, and medical and interdisciplinary care 6,7. Obesity management poses a challenge to Brazilians PHC units, requiring intersectoral actions that must be continuously performed by multidisciplinary teams 6 . A systematic review of randomized controlled trials of nutritional interventions for the weight management of individuals with obesity attending healthcare centers in United States, Canada, England, New Zealand, Mexico, and Australia reported an equally challenging scenario when compared to that found in Brazil 5.

PHC is the preferred entry level of the Brazilian public health system, coordinating care provision within the network. The PHC is essentially centered on the Family Health Strategy (FHS), which consists of a care team (doctor, nurse, nursing assistant, and community healthcare agents) that provides health surveillance; health promotion; disease prevention; continuous care for individuals, families, and communities; and integrated ambulatory and hospital care 8 . All teams receive matrix support and permanent education from multidisciplinary teams called eNASF-AP (Team of the Extended Family Health and Primary Care Center) and health promotion services called Health Academy Program 9,10. Health Academy Program are public spaces that promote health by offering free and regular physical activity, healthy eating, and community education 11 .

Evaluating the quality of PHC is important to improve the care provided, including that aimed at obesity, by identifying and properly addressing eventual challenges and potentially multiplying successful programs and projects 12. In 2011, the Brazilian Ministry of Health proposed the National Program for Improving Primary Care Access and Quality (PMAQ) - a pay-for-performance voluntary initiative where participating PHC units and teams were evaluated based on their structure, work process, and outcomes. Teams and services with the most favorable results received financial incentives, while those with poor performance committed to make improvements before being re-evaluated 13 .

The PMAQ sought to yield improvements in the quality of care by qualifying, monitoring, and evaluating health services. Although several studies approached the program results regarding access to primary care and user satisfaction, data on the quality of obesity management is still scarce $14,15,16,17$. Thus, we described the adequacy of Brazilian PHC units regarding structure and work process for obesity management using data from PMAQ, besides evaluating user satisfaction with PHC services.

\section{Methods}

\section{Study design and PMAQ}

This descriptive study examined data from the second cycle of the PMAQ (2013-2014), conducted in PHC units.

We assessed the following PMAQ evaluation instruments: (i) observation in the PHC unit; (ii) interview with a FHS professional and verification of the unit documents; and (iii) interview with 
users of the PHC unit. Further details on PMAQ and its methodology can be found at: https://aps. saude.gov.br/ape/pmaq.

\section{Sampling and data collection}

Data were collected between 2013-2014 through interviews conducted by trained interviewers with FHS professionals and four users per care team.

Users were characterized according to gender (male, female); age (years); ethnicity according to the classification of the Brazilian Institute of Geography and Statistics - IBGE (White, Black, mixedrace, Asian/Indigenous); education level (illiterate/some elementary or middle school, elementary or middle school/some high school, high school/some higher education, university degree); monthly personal income (< 1 minimum wage, 1-3 minimum wage, 4-6 minimum wage, 7-9 minimum wage, $\geq 10$ minimum wage); and self-reported arterial hypertension and diabetes mellitus, as well as according to municipality characteristics (geographic region: North, Northeast, Central-West, Southeast, and South).

\section{Data organization}

Our analysis was performed based on the conceptual framework proposed by Donabedian 18 .

Three indicators were created to evaluate PHC structure and work process for obesity management, namely: (i) adequate structure - equipment, human resources, and facilities; (ii) adequate access - available collective and individual healthcare interventions; and (iii) adequate service organization and management - systematization of procedures, adequate use of medical records, matrix support and permanent education.

We also evaluated user satisfaction with PHC services. Figure 1 shows the detailed indicators, and Supplementary Material (http://cadernos.ensp.fiocruz.br/static//arquivo/suppl-e00051620-inglesii_4523.pdf) shows the questions from the data collection instrument. All indicators were created within the article scope based on data from the PMAQ.

The first indicator addresses components regarding structure that are considered essential for obesity management. Given that nutritional diagnosis of obesity is performed by the body mass index (BMI) and thus based on height and weight measurements, the minimum combined presence of anthropometer, $200 \mathrm{~kg}$ scale, and the extended team was considered as adequate structure. According to the literature, the interprofessional approach is also indispensable for treatment success 5 . Information regarding structure were obtained from Module I of the data collection instrument (Figure 1 and Supplementary Material: http://cadernos.ensp.fiocruz.br/static//arquivo/suppl-e00051620-ingles-ii_4523.pdf.

The second indicator was related to work process and addressed the essential components of adequate access to obesity care. The minimum combined presence of nutritional assessment, collective health education, and appointments for users with obesity was considered as adequate access. As for the third indicator, the minimum combined presence of records on users with obesity, matrix support from eNASF-AP, and pre-established approach for obesity management was considered as adequate service organization and management. These aspects are included within all guidelines for the care of individuals with obesity in the country 6,19. Information about access and service organization were obtained from Module II of the data collection instrument (Figure 1 and Supplementary Material: http://cadernos.ensp.fiocruz.br/static//arquivo/suppl-e00051620-ingles-ii_4523.pdf).

Information on user satisfaction were obtained from Module III of the data collection instrument, based on the question: "In your opinion, the care received from the healthcare team is...: "very good/ good"; "regular"; or "poor/very poor" (Figure 1 and Supplementary Material: http://cadernos.ensp. fiocruz.br/static//arquivo/suppl-e00051620-ingles-ii_4523.pdf).

\section{Statistical analysis}

All analyses were conducted using Stata version 14 (https://www.stata.com), with significance level set at $5 \%$. 
Figure 1

Flowchart structure and work process.

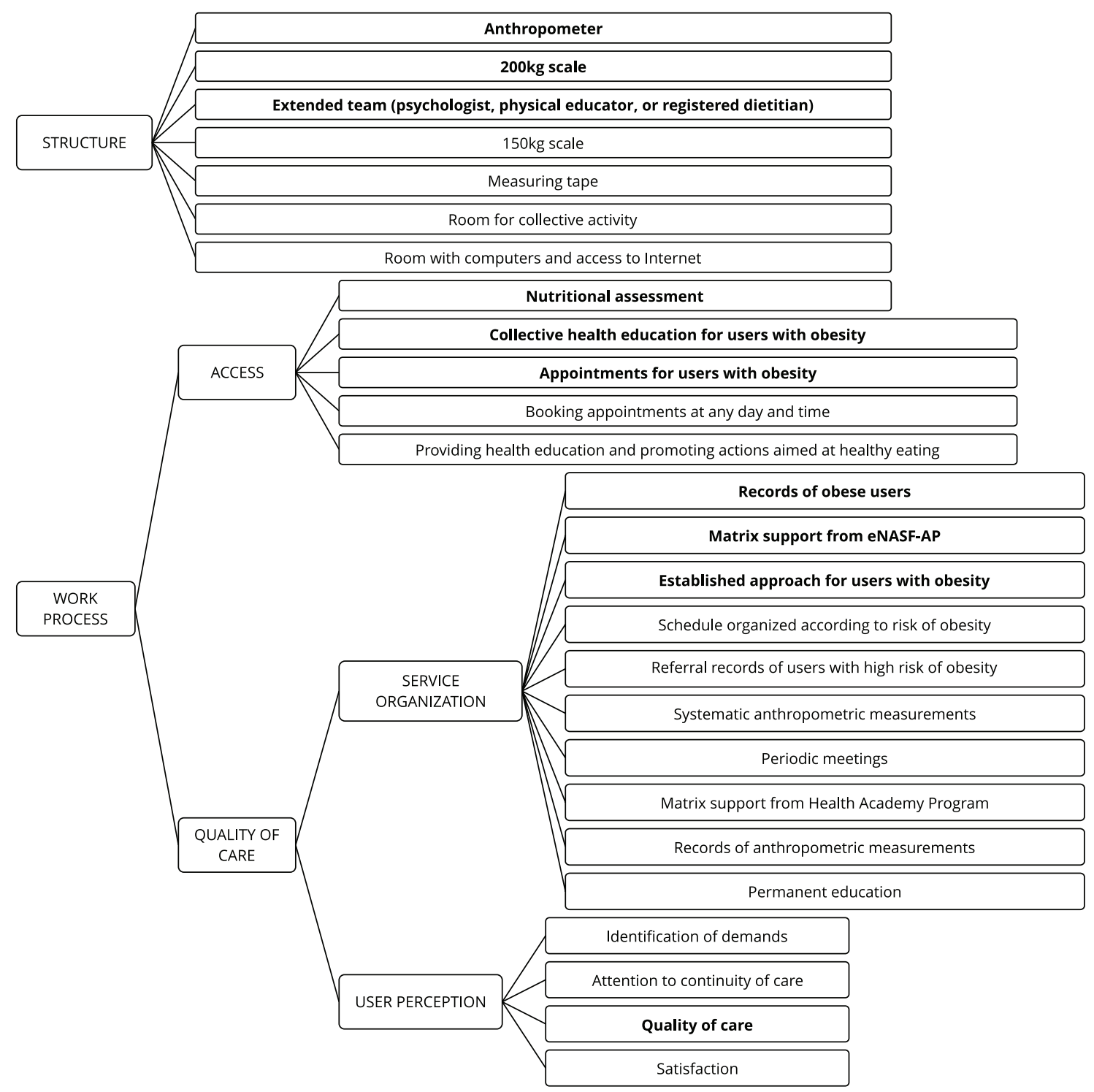

eNASF-AP: Team of the Extended Family Health and Primary Care Center.

Note: questions in bold evaluated adequate "structure", "access" and "service organization and management".

A descriptive analysis of quantitative variables was performed using median and $95 \%$ confidence intervals $(95 \% \mathrm{CI})$. Frequency distributions were calculated for categorical variables. Adequate structure, access, and service organization were described according geographic regions and sociodemographic and health characteristics of public health center users according to satisfaction. Differences between sample characteristics by region were identified by $95 \% \mathrm{CI}$.

This study was conducted according to the guidelines established in the Declaration of Helsinki, and all procedures involving human participants were approved by the Federal University of Pelotas, under number 21494013.0.0000.5317. All participants provided written consent before data collection. 


\section{Results}

We evaluated data from 24,065 PHC units of 4,845 Brazilian cities and 114,615 PHC users.

Most users were women (79.6\%) and 46.1\% self-reported mixed-race and 36.6\% white. More than half of the sample reported being illiterate or having some elementary or middle school (51.1\%) and monthly income between 1 and 3 times the Brazilian minimum wage (67.7\%). Respondents were concentrated in the Northeast (35.1\%) and Southeast regions (34.5\%). Moreover, 37.6\% of the participants reported presenting arterial hypertension and 13.7\% diabetes (Table 1).

Table 1

Sociodemographic and health characteristics of primary healthcare units users by satisfaction. Brazil, $2013-2014$.

\begin{tabular}{|c|c|c|c|c|c|}
\hline \multirow[t]{3}{*}{ Variable } & \multirow[t]{3}{*}{$\mathbf{n}$} & \multirow[t]{3}{*}{ Total } & \multicolumn{3}{|c|}{ Satisfaction } \\
\hline & & & Very good/Good & Regular & Poor/Very Poor \\
\hline & & & \multicolumn{3}{|c|}{ \% or median (P25-P75) } \\
\hline \multirow[t]{2}{*}{ Age (years) [median] $(n=114,615)$} & - & $43(30-58)$ & 44 & 39 & 37 \\
\hline & & & $(31-59)$ & $(28-55)$ & $(28-52)$ \\
\hline Gender $[\%](n=114,615)$ & - & - & & & \\
\hline \multirow[t]{2}{*}{ Male } & 23,412 & 20.4 & 21.0 & 17.8 & 16.5 \\
\hline & & & $(20.7-21.3)$ & $(17.3-18.4)$ & $(15.1-18.1)$ \\
\hline \multirow[t]{3}{*}{ Female } & 91,203 & 79.6 & 79.0 & 82.1 & 83.4 \\
\hline & & & $(78.7-79.2)$ & & $(81.9-84.9)$ \\
\hline & & & & $(81.6-82.7)$ & \\
\hline Race/Ethnicity [\%] ( $\mathrm{n}=112,472)$ & - & & & & \\
\hline \multirow[t]{2}{*}{ White } & 41,145 & 36.6 & 38.0 & 29.9 & 30.3 \\
\hline & & & $(37.7-38.3)$ & $(29.2-30.6)$ & $(28.4-32.3)$ \\
\hline \multirow[t]{3}{*}{ Black } & 15,010 & 13.3 & 13.0 & 14.5 & 16.1 \\
\hline & & & $(12.8-13.3)$ & & \\
\hline & & & & $(14.0-15.0)$ & $(14.7-17.7)$ \\
\hline \multirow[t]{2}{*}{ Mixed-race } & 51,909 & 46.1 & 45.1 & 51.2 & 48.7 \\
\hline & & & $(44.8-45.4)$ & $(50.5-51.9)$ & $(46.7-50.8)$ \\
\hline \multirow[t]{2}{*}{ Asian/Indigenous } & 4,408 & 3.9 & 3.8 & 4.4 & 4.7 \\
\hline & & & $(3.7-3.9)$ & $(4.1-4.7)$ & $(3.9-5.7)$ \\
\hline Education level (years) [\%] $(n=114,615)$ & - & - & & & \\
\hline \multirow[t]{2}{*}{ Illiterate/Some elementary or middle school } & 58,517 & 51.1 & 51.3 & 49.9 & 48.7 \\
\hline & & & $(51.0-51.6)$ & $(49.2-50.1)$ & $(46.7-50.8)$ \\
\hline \multirow[t]{2}{*}{ Elementary or middle school/Some high school } & 24,135 & 21.1 & 20.7 & 22.7 & 22.9 \\
\hline & & & $(20.4-21.0)$ & $(22.1-23.3)$ & $(21.2-24.7)$ \\
\hline \multirow[t]{2}{*}{ High school/Some higher education } & 27,918 & 24.4 & 24.2 & 25.0 & 25.6 \\
\hline & & & $(23.9-24.5)$ & $(24.4-25.7)$ & $(23.8-27.4)$ \\
\hline \multirow[t]{2}{*}{ University degree } & 4,045 & 3.5 & 3.8 & 2.3 & 2.8 \\
\hline & & & $(3.6-3.9)$ & $(2.1-2.5)$ & $(2.2-3.6)$ \\
\hline Monthly personal income (minimum wage) $[\%](n=32,440)$ & - & - & & & \\
\hline \multirow[t]{2}{*}{$<1$} & 9,316 & 28.7 & 27.8 & 32.6 & 34.7 \\
\hline & & & $(27.3-28.4)$ & (31.3-33.9) & $(31.2-38.3)$ \\
\hline \multirow[t]{2}{*}{$1-3$} & 21,958 & 67.7 & 68.3 & 65.1 & 62.7 \\
\hline & & & $(67.7-68.9)$ & $(63.7-66.4)$ & $(59.0-66.2)$ \\
\hline \multirow[t]{2}{*}{$>4$} & 1,166 & 3.6 & 3.8 & 2.3 & 2.6 \\
\hline & & & $(3.6-4.1)$ & $(1.9-2.8)$ & $(1.7-4.1)$ \\
\hline
\end{tabular}

(continues) 
Table 1 (continued)

\begin{tabular}{|c|c|c|c|c|c|}
\hline \multirow[t]{3}{*}{ Variable } & \multirow[t]{3}{*}{$\mathbf{n}$} & \multirow[t]{3}{*}{ Total } & \multicolumn{3}{|c|}{ Satisfaction } \\
\hline & & & Very good/Good & Regular & Poor/Very Poor \\
\hline & & & \multicolumn{3}{|c|}{ \% or median (P25-P75) } \\
\hline \multicolumn{6}{|l|}{ Geographic region $[\%](n=114,615)$} \\
\hline North & 8,507 & 7.4 & $\begin{array}{c}6.8 \\
(6.7-7.0)\end{array}$ & $\begin{array}{c}10.2 \\
(9.7-10.6)\end{array}$ & $\begin{array}{c}8.9 \\
(7.8-10.2)\end{array}$ \\
\hline Northeast & 40,292 & 35.1 & $\begin{array}{c}33.7 \\
(33.4-34.0)\end{array}$ & $\begin{array}{c}42.2 \\
(41.4-42.8)\end{array}$ & $\begin{array}{c}42.4 \\
(40.4-44.4)\end{array}$ \\
\hline Southeast & 39,551 & 34.5 & $\begin{array}{c}35.5 \\
(35.2-35.8)\end{array}$ & $\begin{array}{c}29.3 \\
(28 .-30.0)\end{array}$ & $\begin{array}{c}32.7 \\
(30.8-34.7)\end{array}$ \\
\hline South & 17,298 & 15.1 & $\begin{array}{c}16.1 \\
(15.8-16.3)\end{array}$ & $\begin{array}{c}10.7 \\
(10.3-11.2)\end{array}$ & $\begin{array}{c}8.7 \\
(7.6-10.0)\end{array}$ \\
\hline Central-West & 8,967 & 7.8 & $\begin{array}{c}7.9 \\
(7.7-8.0)\end{array}$ & $\begin{array}{c}7.7 \\
(7.3-8.1)\end{array}$ & $\begin{array}{c}7.2 \\
(6.2-8.3)\end{array}$ \\
\hline Systemic hypertension $[\%](n=114,203)$ & - & - & & & \\
\hline No & 71,209 & 62.3 & $\begin{array}{c}61.2 \\
(60.9-61.5)\end{array}$ & $\begin{array}{c}67.3 \\
(66.6-68.0)\end{array}$ & $\begin{array}{c}70.6 \\
(68.6-72.4)\end{array}$ \\
\hline Yes & 42,994 & 37.6 & $\begin{array}{c}38.8 \\
(38.5-39.1)\end{array}$ & $\begin{array}{c}32.6 \\
(32.0-33.3)\end{array}$ & $\begin{array}{c}29.4 \\
(27.6-31.4)\end{array}$ \\
\hline Diabetes mellitus [\%] $(n=113,528)$ & - & - & & & \\
\hline No & 97,971 & 86.3 & $\begin{array}{c}85.7 \\
(85.5-85.9)\end{array}$ & $\begin{array}{c}10.9 \\
(10.5-11.4)\end{array}$ & $\begin{array}{c}10.3 \\
(9.1-11.6)\end{array}$ \\
\hline Yes & 15,557 & 13.7 & $\begin{array}{c}14.3 \\
(14.1-14.5)\end{array}$ & $\begin{array}{c}10.9 \\
(10.5-11.4)\end{array}$ & $\begin{array}{c}10.3 \\
(9.1-11.6)\end{array}$ \\
\hline
\end{tabular}

Of the seven items used to evaluate services structure, three had prevalence greater than $80 \%$. Among the essential items (anthropometer, 200kg scale, and extended team), only the anthropometer was included within the structure of more than half units (88.9\%) (Figure 2).

A total of $7.6 \%$ of PCH units presented an adequate structure (combined presence of the essential items), with higher prevalence in the South and Southeast regions (14.6\% and 14\%, respectively, p < 0.001) (Figure 3).

Regarding the essential items for adequate access to obesity care, $64.1 \%$ of PHC units included nutritional assessment, $57.1 \%$ collective health education, and $46.3 \%$ medical appointments for users with obesity (Figure 2). Based on our study criteria, only $26.6 \%$ of the units presented adequate access to obesity care, with lower prevalence in the North Region $(18.9 \%, \mathrm{p}<0.001)$ (Figure 3).

As for service organization and management, $36.4 \%$ presented records on users with obesity, 57.6\% matrix support from eNASF-AP, and 96.9\% an established approach for obesity management (Figure 2). Considering the combined presence of essential items, $27.8 \%$ were considered to have an adequate service organization, with higher prevalence in the Southeast and Northeast $(32.8 \%$ and $28.2 \%$, respectively, $\mathrm{p}<0.001$ ) (Figure 3 ).

Over $80 \%$ of respondents rated the care provided as good or very good (user satisfaction) (Figure 4), with higher prevalence in the South and Southwest regions. Reports of poor or very poor quality of care were significantly higher in North and Northeast (Figure 4). 


\section{Figure 2}

Distribution of components of structure, access, and service organization and management. Brazil, 2013-2014.

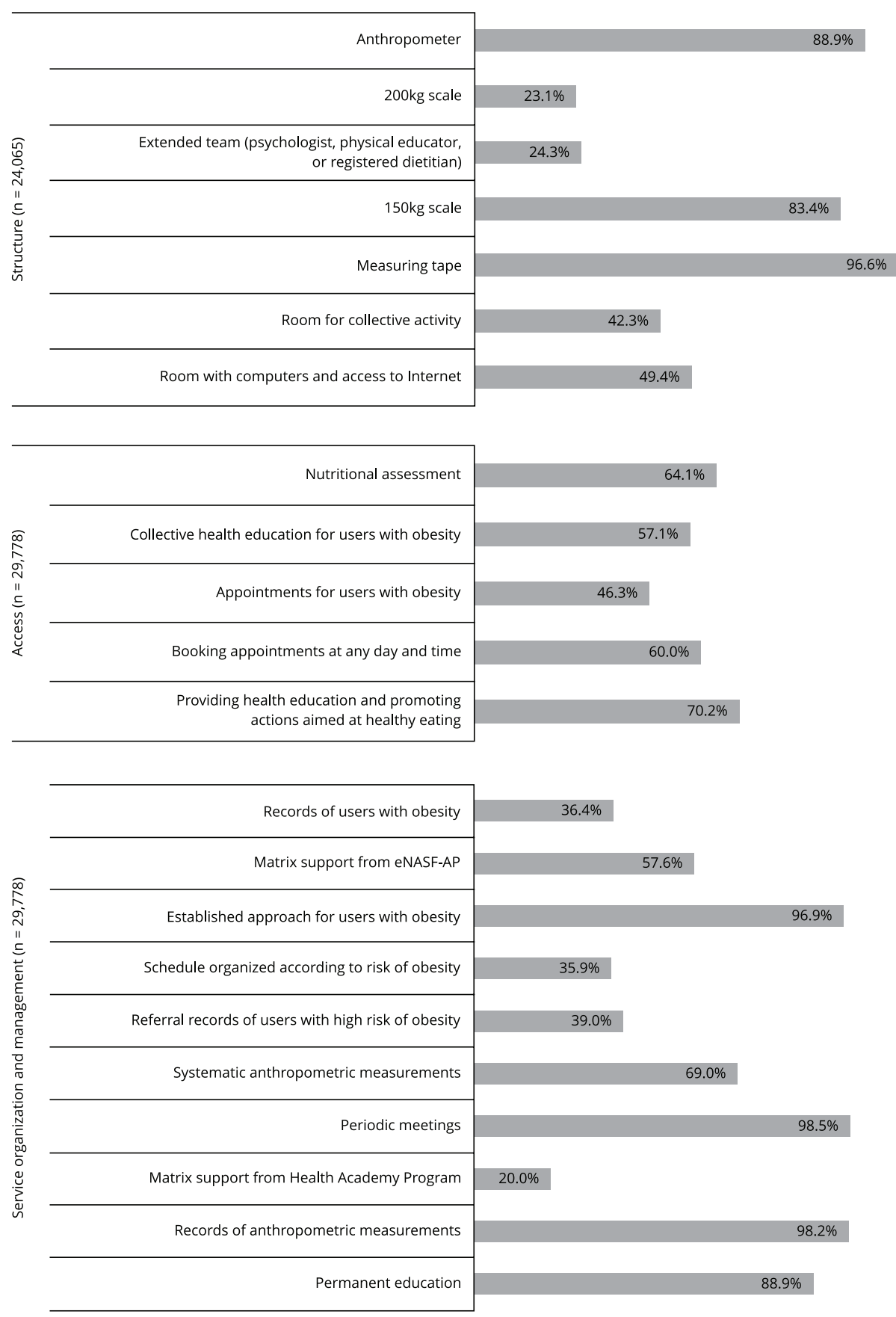

eNASF-AP: Team of the Extended Family Health and Primary Care Center. 
Figure 3

Distribution of adequate structure, access, and service organization and management according to region. Brazil, 2013-2014.

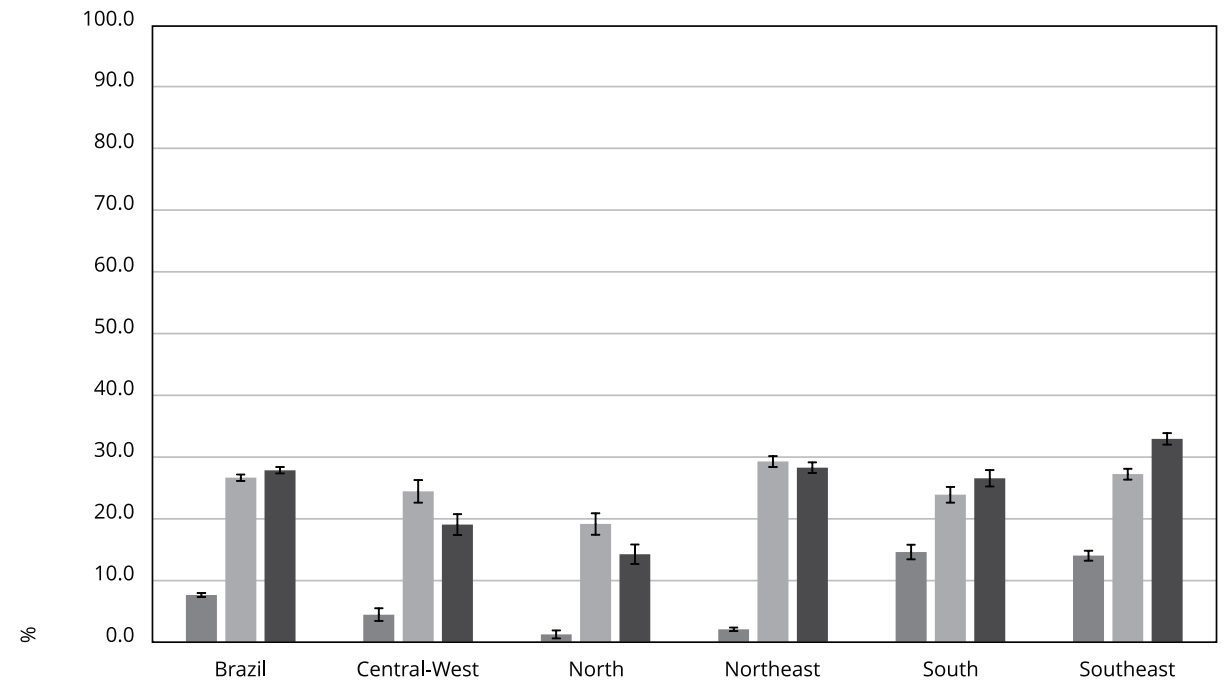

Adequate structure *

Adequate access **

Adequate service organization ***

* Brazil $(n=1,824)$; Central-West $(n=83)$; North $(n=20)$; Northeast $(n=196)$; South $(n=525)$; Southeast $(n=1,000)$

** Brazil $(n=7,933)$; Central-West $(n=548)$; North $(n=413)$; Northeast $(n=3,148)$; South $(n=1,079)$; Southeast $(n=2,745)$;

*** Brazil $(n=8,291)$; Central-West $(n=426)$; North $(n=307)$; Northeast $(n=3,040)$; South $(n=1,197)$; Southeast $(n=3,321)$.

\section{Figure 4}

Prevalence of users' satisfaction with primary healthcare services (95\% confidence intervals) according to region. Brazil, $2013-2014$.

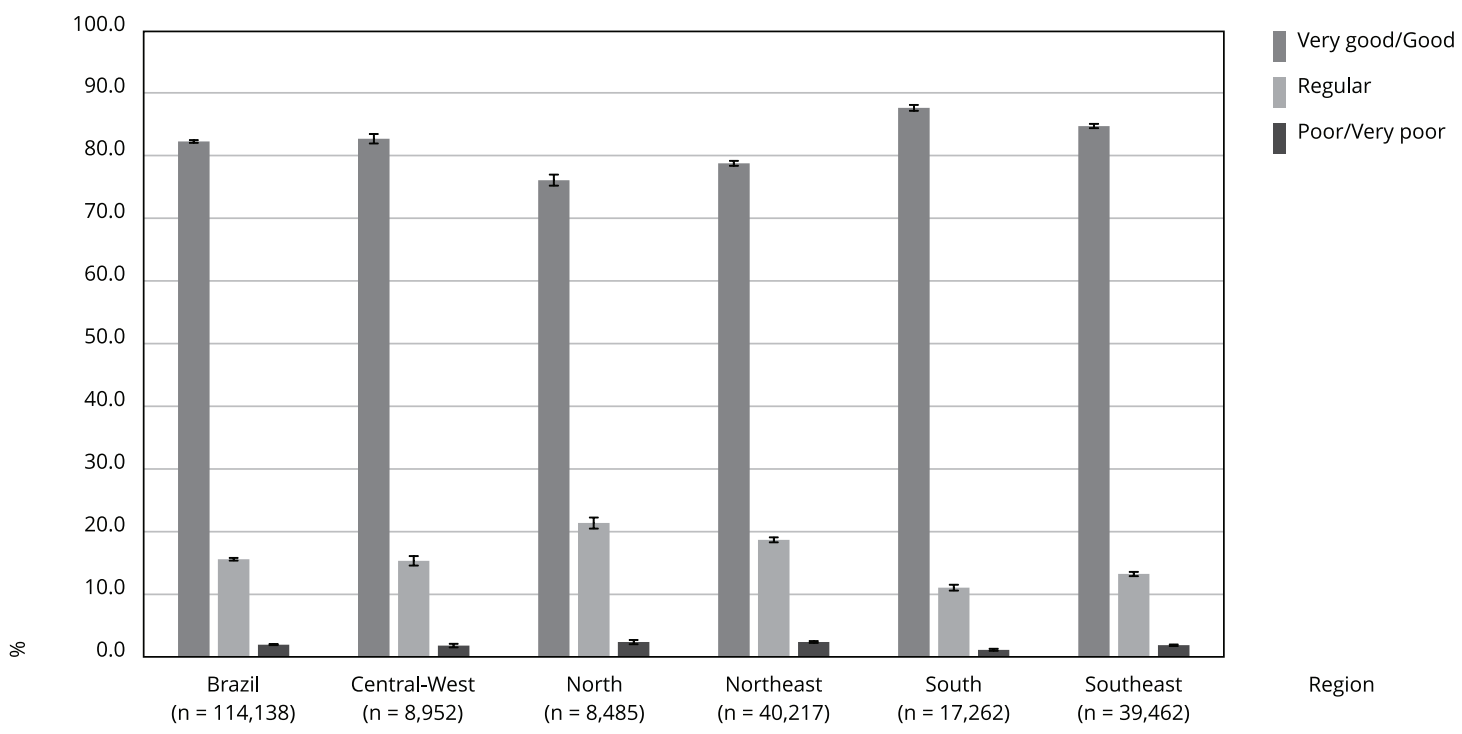




\section{Discussion}

The management of obesity within PHC units in Brazil raises legitimate concerns regarding structure, access, organization, and management, especially in the North Region. We verified low adequacy regarding some of the items considered essential for obesity care, such as $200 \mathrm{~kg}$ scales, extended team (psychologist, physical educator or registered dietitian), and records on users with obesity - present in less than $40 \%$ of PHC units. This scenario highlights the need for improvement to ensure a broader and more effective prevention and treatment of obesity within PHC.

Diagnostic and therapeutic support is essential for PHC to be more resolute in controlling obesity. For that, an adequate infrastructure (appropriate scales, chairs, access ramps, etc.), teams' size and composition, initiatives supply and access, and the management of demands and flows plays a key role in achieving better health outcomes 6 .

We found less than $8 \%$ of the units to present an adequate structure, especially regarding the low frequency of extended teams, rooms for collective activities, and 200kg scales. Services structure and available materials tend to affect the resolution and comprehensiveness of PHC actions. Considering that more than $3 / 4$ of the population exclusively uses the public health system and that more than 1 million Brazilians have severe obesity 20, the lack of adequate structure for diagnosing, evaluating, and monitoring obesity may lead to poorer quality care, increased risk of obesity-related complications and, consequently, increased healthcare spending.

With the Brazilian National Food and Nutrition Policy (PNAN) update in 2011, Brazil has received financial support and material that summarizes the description of anthropometric equipment that can be purchased and used in health services, including digital and/or mechanical $200 \mathrm{~kg}$ scales ${ }^{21}$. For that, managers must determine together with health professionals the required equipment to assist the local population. Before the availability of resources, we must identify the barriers to acquiring $200 \mathrm{~kg}$ scales. Our hypothesis is that the diagnosis of the local needs is faulty, just as bureaucracies involved in equipment acquisition may demotivate managers. Further investigations are required to provide a better understanding of these issues.

Despite considerable advances 22, less than 1/4 of PHC units presented professionals on psychology, physical education, and nutrition - a markedly insufficient amount to meet the growing demand imposed by the obesity epidemic in the country. These findings indicate that obesity management within PHC units is still limited, impairing services credibility and the consolidation of initiatives focused on the PNAN 15,23,24. The new funding model for the Brazilian PHC may actually worsen this scenario, given that it no longer encourages municipalities to maintain interprofessional support teams.

A more appropriate structure could improve access and management criteria, including the adequacy of nutritional assessment, collective actions, matrix support, and appointments for and records on users with obesity. Although considered a priority by the Brazilian Ministry of Health 6 , only a little more than a third of PHC units keep records of users with obesity and their referrals to other healthcare services and organize appointments according to the risk of obesity. About $2 / 3$ of the units reported performing nutritional assessment; however, the considerable inadequacy of records on nutritional diagnosis and of care strategies definition according to risk stratification may result in low effectiveness due to non-specificity as to each individual's demands.

These results suggest that the systematic management for obesity is still incipient in the country, as well as the care aimed at overweight and obesity. In Brazil, the Ordinance n. 424/2013 redefined the care line for overweight and obesity, defending integrity within the network and providing longitudinal and multi-professional assistance by identifying individuals with obesity and stratifying their risk 6,11. However, 2013-2014 data from the PMAQ is almost simultaneous to the creation of this care line, so that our results justify its creation and indicate the need for continuous evaluation to verify whether these gaps have been bridged since then. Considering primary care attributions and the care line implementation, further assessment is essential to expand and improve the national proposal.

A quality care and successful implementation of the overweight and obesity care line requires a specialized and interdisciplinary team, which must stratify the risk for obesity, encourage self-care, and highlight users' role in their own treatment. The team must also provide care for individuals with 
associated comorbidities and monitor those who have undergone obesity-related surgical procedures, thus fostering treatment success 5,25,26.

The performance of multiprofessional teams is essential for ensuring comprehensive and longitudinal care for people with obesity in PHC. Nearly all interviewed teams reported holding periodic meetings, but those relying on matrix support from eNASF-AP and Health Academy Program were less frequent. Having different professionals in PHC units is ineffective if actions are not based on matrix support. In that sense, teams' adequate performance goes far beyond simply holding team meetings, including deeper interprofessional collaborative work, clinical assistance, and technical and pedagogical support 4 . Thus, our results may express a misunderstanding of the concept of matrix support or a difficulty in jointly implementing therapeutic projects $24,27,28$.

Generally speaking, the care provided for users with obesity in Brazilian PHC services is still precarious, with significant disparities among regions 15. Based on our indicators, the North Region often presented the lowest prevalence of adequacy whereas the Southeast had more favorable results, reinforcing the regional inequalities in the country. Another interesting comparison refers to the Northeast and the South - historically, the Northeast has the highest coverage rates by FHS teams; in turn, not only was the FHS lately implemented in the South compared with other regions, but it also has a lower coverage rate 29,30 . These data might explain why the Northeast presents better indicators of access, organization, and management despite the significantly lower levels of development and structure.

Regardless of the limitations of PHC centers and their teams in providing adequate obesity care, at least 3/4 of the users rated the care as very good or good. Corroborating our results, a national study revealed that $76.7 \%$ of PHC users were satisfied with the serviced provided. The main factors associated with user satisfaction were related to humanized care (e.g., feeling respected by the health professionals) and health centers structure, process, and operational conditions (e.g., short distance from home to the centers, operation hours, access to make an appointment, and room with privacy) 31. User satisfaction with PHC services strengthens community control, empowerment, and participation in the planning and evaluation processes, besides assisting managers and stakeholders in the decision-making process and establishing shared accountability for care provision 31 .

\section{Study limitations}

Our results should be generalized with caution. First, adherence to PMAQ was voluntary, and the participation of PHC units and FHS teams may not be random for only the most engaged centers and best teams tend to enroll. However, such voluntary adherence provide knowledge on PHC units that approach the highest quality standards expected for the Brazilian context.

Second, our results refer to the second cycle of PMAQ. Although the third cycle has already been performed, investigating new variables, its data were not available at the time of our analysis.

Third, our sampling method was not random, so that selection bias may have occurred, affecting satisfaction results. However, the respondents were regular users of PHC units and thus assumed to be representative of the overall set of users. Our interviewees were also not necessarily the users with obesity, hindering the evaluation of obesity care from those patients' perspective.

Our results should be interpreted considering that the quantitative nature of PMAQ evaluations may not reflect the complexity of obesity management and Brazilian PHC in its entirety. Our indicators were not validated quantitatively, but the questions that make them up were developed by PMAQ experts and researchers, and their application was tested in different project cycles. Moreover, the items that compose each indicator were chosen based on a review of the national and international literature 6,11,32,33,34,35, added to the research group previous experience. All indicators were validated by technicians from the Brazilian Ministry of Health and primary care professionals. Finally, the literature indicating which indicators to use is scarce, and our results can contribute to this discussion and new studies on the topic. 


\section{Study strengths}

To the best of our knowledge, this is the first study to investigate the adequacy of the structure and work process regarding obesity management in the Brazilian PHC. We also addressed the national scope and employed standardized instruments, allowing comparisons between regions. PMAQ might have been the world's largest pay-for-performance program in PHC, transcending external evaluations. By inducing team's self-assessment and identifying priorities from users' perspective, the initiative contributes to reorienting services in search of a greater resoluteness. Considering the rising prevalence of obesity, actions aimed at increasing the quality of care, such as the PMAQ, may help reducing this condition health, social, and economic impacts.

\section{Suggestions}

We identified aspects that should be improved in the obesity management in Brazilian PHC. Potentially important variables that were not included in the second cycle of PMAQ were (i) the presence of larger measuring tapes for the accurate waist measurement of users with severe obesity; (ii) number of seats with dimensions suitable for individuals with obesity, as a person with obesity needs adequate environments and accessible furniture to promote their social inclusion; and (iii) measured or self-reported weight and height for BMI calculation and obesity classification. Provided these variables, obesity care evaluation on the perspective of those with this chronic disease will probably be more accurate.

PMAQ data have a great strategic importance for providing a comprehensive view of access and quality in obesity management, improving care provision while evaluating its evolution. After three evaluation cycles conducted until 2018, reaching around 40,000 primary care teams, a new financing model for primary care was instituted in the country in January 2020. The Programa Previne Brasil in português, changed some ways of transferring transfers to the municipalities. In this model, the pay for performance considers the results achieved in a set of seven indicators. However, these indicators may not combine specific actions for the proper management of obesity, one of the main public health problems in the country. We emphasize that all governments Brazilians over time must guarantee programs to improve the quality of $\mathrm{PHC}$, with the objective of improving the national health system.

\section{Conclusions}

This is the first study to investigate the adequacy of structure and work processes regarding obesity management in the Brazilian PHC. Our results suggest that the country is still in the initial stages of systematizing obesity care, showing significant disparities among regions. Thus, the structure, access, and organization of Brazilian PHC units must be improved to provide an adequate care toward obesity, justifying the need for higher investments in this care line to reverse this situation. 


\section{Contributors}

M. S. Lopes and P. P. Freitas participated in data curation, formal analysis and interpretation of data, writing, review and approval of the final version of the text. N. L. Ferreira and M.C. Menezes collaborated in the writing, revision and approval of the final version of the text. A. C. S. Lopes contributed in the methodological stage, in the writing, revision and approval of the final version of the text.

\section{Additional informations}

ORCID: Mariana Souza Lopes (0000-0003-31287959); Patrícia Pinheiro de Freitas (0000-00019355-3066); Maria Cecília Ramos de Carvalho (0000-0002-8947-2121); Nathália Luíza Ferreira (0000-0002-2751-2458); Mariana Carvalho de Menezes (0000-0002-3069-7959); Aline Cristine Souza Lopes (0000-0001-9782-2606).

\section{Acknowledgments}

We thank Olivia Lucena de Medeiros, Raquel de Deus Mendonça, Kelly Alves Magalhães, Mariana Oliveira Martiniano, Lorena Neiva de Oliveira, and Mônica Rocha Gonçalves. The Pan-American Health Organization (PAHO/Brazil); the ProRectory of Research of the Universidade Federal de Minas Gerais; Brazilian Graduate National Research Council (CNPq); Minas Gerais State Research Foundation (FAPEMIG); and Graduate Studies Coordinating Board (CAPES) for the financial support.

\section{References}

1. The GBD 2015 Obesity Collaborators. Health effects of overweight and obesity in 195 countries over 25 years. N Engl J Med 2017; 377:13-27.

2. Departamento de Vigilância de Doenças e Agravos não Transmissíveis e Promoção da Saúde, Secretaria de Vigilância em Saúde, Ministério da Saúde. Vigitel Brasil 2018: vigilância de fatores de risco e proteção para doenças crônicas por inquérito telefônico: estimativas sobre frequência e distribuição sociodemográfica de fatores de risco e proteção para doenças crônicas nas capitais dos 26 estados brasileiros e no Distrito Federal em 2018. Brasília: Ministério da Saúde; 2019.

3. González-Muniesa P, Mártinez-González MA, Hu FB, Després JP, Matsuzawa Y, Loos RJF, et al. Obesity. Nat Rev Dis Primers 2017; 3:1-18.

4. Reis EC, Passos SRL, Santos MAB. Quality assessment of clinical guidelines for the treatment of obesity in adults: application of the AGREE II instrument. Cad Saúde Pública 2018; 34:e0050517.

5. Menezes MC, Duarte CK, Costa DVP, Lopes MS, Freitas PP, Campos SF, et al. A systematic review of effects, potentialities, and limitations of nutritional interventions aimed at managing obesity in primary and secondary health care. Nutrition 2020; 75-76:110784.

6. Departamento de Atenção Básica, Secretaria de Atenção à Saúde, Ministério da Saúde. Estratégias para o cuidado da pessoa com doença crônica: obesidade. Brasília: Ministério da Saúde; 2014.

7. Beaglehole R, Epping-Jordan J, Patel V, Chopra $\mathrm{M}$, Ebrahin $\mathrm{S}$, et al. Improving the prevention and management of chronic disease in low-income and middle-income countries: a priority for primary health care. Lancet 2008; 372:940-9.

8. Paim J, Travassos C, Almeida C, Bahia L, Macinko J. The Brazilian health system: history, advances, and challenges. Lancet 2011; 377:1778-97.

9. Carvalho MN, Gil CRR, Costa EMOD, Sakai $\mathrm{MH}$, Leite SN. Needs and dynamics of the primary healthcare workforce in Brazil. Ciênc Saúde Colet 2018; 23:295-302.

10. Fernandes AP, Andrade ACS, Costa DADS, Dias MAS, Malta DC, Caiaffa WT. Health Academies Program and the promotion of physical activity in the city: the experience of Belo Horizonte, Minas Gerais State, Brazil. Ciênc Saúde Colet 2017; 22:3903-14.

11. Ministério da Saúde. Portaria no 2.681, de 7 de novembro de 2013. Redefine o Programa Academia da Saúde no âmbito do Sistema Único de Saúde (SUS). Diário Oficial da União 2013; 7 nov.

12. Souza MF, Santos AF, Reis IA, Santos MAC, Jorge AO, Machado ATGM, et al. Coordenação do cuidado no PMAQ-AB: uma análise baseada na Teoria de Resposta ao Item. Rev Saúde Pública 2017; 51:87. 
13. Macinko J, Harris MJ, Rocha MG. Brazil's National Program for Improving Primary Care Access and Quality (PMAQ) fulfilling the potential of the world's largest payment for performance system in primary care. J Ambul Care Manage 2017; 40:4-11.

14. Fausto MCR, Bousquat A, Lima JG, Giovanella L, Almeida PF, Mendonça MHM, et al. Evaluation of Brazilian primary health care from the perspective of the users accessible, continuous, and acceptable? J Ambul Care Manage 2017; 40:60-70.

15. Neves M, Giordani JMA, Ferla A, Hugo FN. Primary care dentistry in Brazil from prevention to comprehensive care. J Ambul Care Manage 2017; 40:35-48.

16. Tomasi E, Cesar MADC, Neves RG, Schmidt PRC, Thumé E, Silveira DS, et al. Diabetes care in Brazil: Program to Improve Primary Care Access and Quality-PMAQ. J Ambul Care Manage 2017; 40:12-23.

17. Medina MG, Aquino R, Vilasbôas ALQ, Mota E, Pinto Júnior EP, Luz LA, et al. Promoção da saúde e prevenção de doenças crônicas: o que fazem as equipes de saúde da família? Saúde Debate 2014; 38:69-82.

18. Donabedian A. Evaluating the quality of medical care. Milbank Q 2005; 83:691-729.

19. Ministério da Saúde. Perspectivas e desafios no cuidado às pessoas com obesidade no SUS: resultados do Laboratório de Inovação no manejo da obesidade nas Redes de Atenção à Saúde. Brasília: Ministério da Saúde; 2014.

20. Kelles SMB, Diniz MFHS, Machado CJ, Barreto SM. Perfil de pacientes submetidos à cirurgia bariátrica, assistidos pelo Sistema Único de Saúde do Brasil: revisão sistemática. Cad Saúde Pública 2015; 31:1587-601.

21. Ministério da Saúde. Portaria no 2.975, de 14 de dezembro de 2011. Apoiar financeiramente a estruturação da Vigilância Alimentar e Nutricional. Diário Oficial da União 2011; 14 dec.

22. Vasconcelos IAL, Sousa MF, Santos LM. Evolução do quantitativo de nutricionistas na Atenção Básica do Brasil: a contribuição dos Núcleos de Apoio à Saúde da Família e da Estratégia Saúde da Família de 2007 a 2013. Rev Nutr 2015; 28:431-50.

23. Flores GMS, Weigelt LD, Rezende MS, Telles R, Krug SBF. Gestão pública no SUS: considerações acerca do PMAQ-AB. Saúde Debate 2018; 42:237-47.

24. Jaime PC, Delmuè DCC, Campello T, Silva DO, Santos LMP. Um olhar sobre a agenda de alimentação e nutrição nos trinta anos do Sistema Único de Saúde. Ciênc Saúde Colet 2018; 23:1829-36.

25. Ministério da Saúde. Portaria no 2.436, de 21 de setembro de 2017. Aprova a Política Nacional de Atenção Básica, estabelecendo a revisão de diretrizes para a organização da Atenção Básica, no âmbito do Sistema Único de Saúde (SUS). Diário Oficial da União 2017; 22 sep.
26. Nicolau IR, Espirito Santo FH, David FM. Trabalho em equipe: em busca de um cuidado qualificado ao obeso. Rev Enferm UFPE on line 2017; 11:152-9.

27. Fonseca Sobrinho D, Machado ATGM, Lima AMLD, Jorge AO, Reis CMR, Abreu DMX, et al. Compreendendo o apoio matricial e o resultado da certificação de qualidade nas áreas de atenção à criança, mulher, diabetes/hipertensão e saúde mental. Saúde Debate 2014; 38(n. spe):83-93.

28. Jorge MSB, Sousa FSP, Franco TB. Apoio matricial: dispositivo para resolução de casos clínicos de saúde mental na atenção primária à saúde. Rev Bras Enferm 2013; 66:738-44.

29. Malta DC, Santos MAS, Stopa SR, Vieira JEB, Melo EA, Reis AAC. Family Health Strategy coverage in Brazil, according to the National Health Survey. Ciênc Saúde Colet 2013; 21:327-38.

30. Secretaria de Políticas de Saúde, Ministério da Saúde; Instituto de Saúde Coletiva, Universidade Federal da Bahia. O Programa de Saúde da Família: evolução de sua implantação no Brasil. Relatório final. Salvador: Instituto de Saúde Coletiva, Universidade Federal da Bahia; 2002.

31. Protásio APL, Gomes LB, Machado LS, Valença AMG. User satisfaction with primary health care by region in Brazil: 1 st cycle of external evaluation from PMAQ-AB. Ciênc Saúde Colet 2017; 22:1829-44.

32. World Health Organization. Obesity: preventing and managing the global epidemic. Report of a WHO Consultation. Geneva: World Health Organization; 2000. (WHO Technical Report Series, 894).

33. National Health and Medical Research Council. Clinical practice guidelines for the management of overweight and obesity in adults, adolescents and children in Australia. Sidney: National Health and Medical Research Council; 2013.

34. Ministério da Saúde. Instrutivo de abordagem coletiva para manejo da obesidade no SUS. Brasília: Ministério da Saúde/Belo Horizonte: Universidade Federal de Minas Gerais; 2021.

35. Ministério da Saúde. Instrutivo para manejo da obesidade no Sistema Único de Saúde: caderno de atividades educativas Brasília: Ministério da Saúde/Belo Horizonte: Universidade Federal de Minas Gerais; 2021. 


\section{Resumo}

O estudo tem como objetivo descrever a adequação das unidades básicas de saúde (UBS) em relação à estrutura e ao processo de trabalho relacionados ao manejo da obesidade, além de avaliar a satisfação dos/as usuários/as com os serviços de saúde. Este estudo transversal foi realizado utilizando dados do Programa Nacional de Melhoria do Acesso e da Qualidade (PMAQ) 2013-2014, uma iniciativa nacional para avaliar o desempenho das equipes de saúde. A coleta de dados ocorreu em 2013 e 2014 através de entrevistas com equipes e usuários/as dos serviços saúde. Todos os indicadores de adequação para o cuidado da obesidade foram criados no âmbito do artigo, com base nos dados do PMAQ. Foram avaliadas 24.055 UBS em 4.845 municípios, além de dados de 114.615 usuários/as. Apenas 7,6\% das UBS analisadas tinham estrutura adequada para o tratamento da obesidade. $O$ acesso adequado foi observado em 26,6\%, e a organização adequada dos serviços foi encontrada para $27,8 \%$ das UBS. Os cuidados de saúde foram classificados como "bons" ou "muito bons" por 82,4\% dos usuários/as. Esses indicadores variaram por região geográfica, com melhores resultados para as regiões Sul e Sudeste. Os resultados sugerem que, possivelmente, o país ainda está na fase inicial de sistematização dos cuidados com a obesidade, com significativas disparidades entre as regiões.

Obesidade; Atenção Primária à Saúde; Qualidade da Assistência à Saúde

\section{Resumen}

El objetivo de este estudio es describir la adecuación de las unidades básicas de atención (UBS) en Brasil, respecto a su estructura y proceso de trabajo para la gestión de la obesidad, así como evaluar la satisfacción de los usuarios con los servicios de las UBS. Este estudio transversal se realizó con datos del 2013-2014 del Programa Nacional de Mejora del Acceso y de la Calidad de la Atención Básica (PMAQ) - una iniciativa para evaluar el desempeño de los equipos de las UBS. Se recogieron datos entre 2013 y 2014 a través de entrevistas a equipos y usuarios de las UBS. Todos los indicadores del cuidado adecuado para la obesidad fueron definidos en el ámbito del artículo, basados en datos del PMAQ. De las 24.055 UBS analizadas, localizadas en 4.845 ciudades diferentes, solamente un 7,6\% tenía una estructura adecuada para la gestión de la obesidad. Asimismo, solo un 26,6\% de los 114.615 usuarios entrevistados de UBS informaron de un acceso adecuado, y un 27,8\% de las UBS presentaron una organización adecuada del servicio. La atención en salud fue considerada como "buena" o "muy buena" por parte de un $82,4 \%$ de los usuarios. Estos indicadores variaron de acuerdo con la región geográfica, mostrando mejores resultados en el Sur y Sureste. Nuestros resultados sugieren que el país tal vez se encuentre todavía en un estadio inicial de sistematización del cuidado con la obesidad, presentando significantes disparidades entre regiones.

Obesidad; Atención Primaria de Salud;

Calidad de la Atención de Salud
Submitted on 19/Mar/2020

Final version resubmitted on 14/Aug/2020

Approved on 26/Aug/2020 